\title{
Working
}

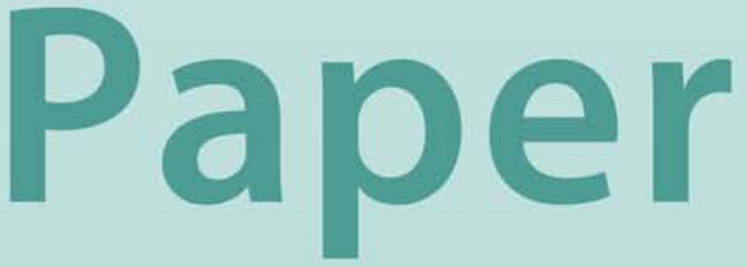




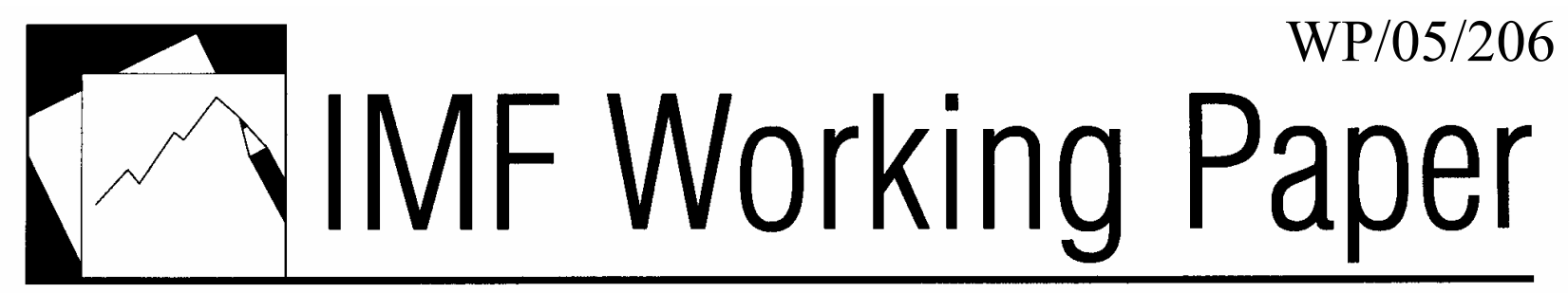

Strengthening IMF Crisis Prevention

Jonathan D. Ostry and Jeromin Zettelmeyer 


\title{
IMF Working Paper
}

Research Department

\section{Strengthening IMF Crisis Prevention}

\author{
Prepared by Jonathan D. Ostry and Jeromin Zettelmeyer $^{1}$
}

November 2005

\begin{abstract}
This Working Paper should not be reported as representing the views of the IMF. The views expressed in this Working Paper are those of the author(s) and do not necessarily represent those of the IMF or IMF policy. Working Papers describe research in progress by the author(s) and are published to elicit comments and to further debate.

To better fulfill its crisis-prevention mandate, IMF surveillance needs to provide stronger incentives for countries to follow good policies and for markets to avoid boom-bust cycles in capital flows. To this end, surveillance should culminate in a summary public assessment of the quality of a country's policies and stipulate the actions needed to address shortcomings. A country's potential access to IMF credits should be linked to the quality of its policies in noncrisis periods in order to create stronger incentives for better policies and reduce incentives for capital to flow where it cannot be used in socially beneficial ways.
\end{abstract}

JEL Classification Numbers: F02, F33, F34

Keywords: International Monetary Fund; Crisis prevention; IMF surveillance

Author(s) E-Mail Address: jostry@imf.org; jzettelmeyer@,imf.org

\footnotetext{
${ }^{1} \mathrm{We}$ are grateful to many colleagues in the Fund for discussions on the subject of IMF reform and comments on earlier drafts of this paper. Without implication, we thank Mark Allen, Jack Boorman, Eduardo Borensztein, Jim Boughton, Olivier Jeanne, Anne Krueger, Tim Lane, and Raghu Rajan. This paper draws on our earlier unpublished paper, "The IMF in the Future: Directions for Reform," September 2004.
} 


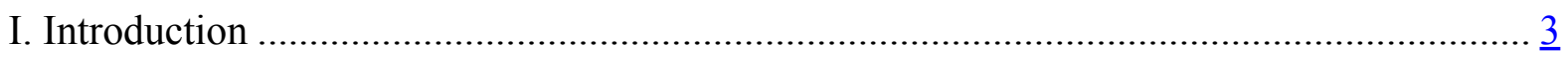

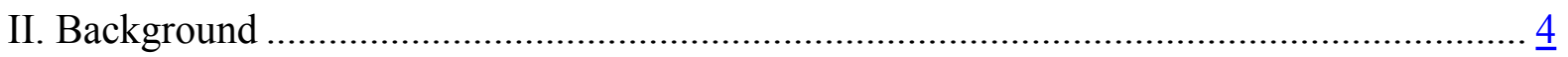

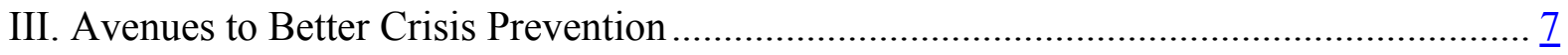

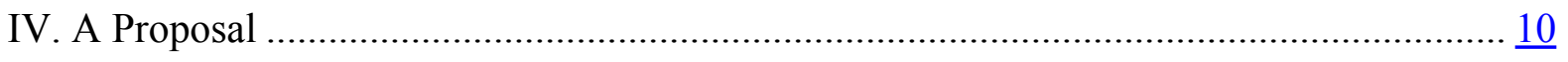

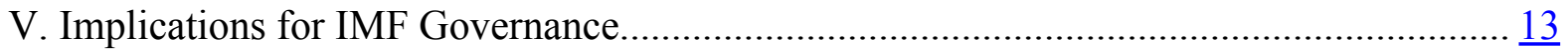

A. Improving the IMF's Ability to Commit ........................................................... 14

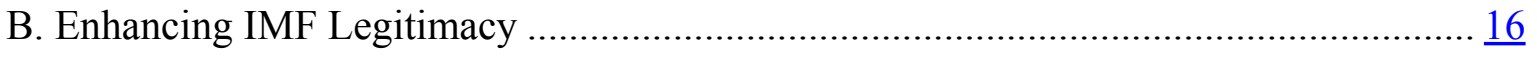

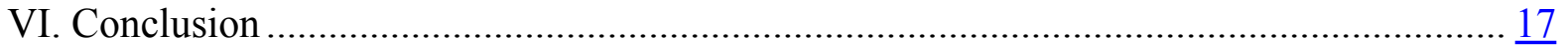

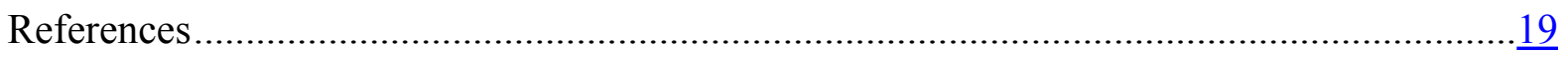

Boxes

1. Designing Prequalification Criteria …................................................................

2. Governance of Some International Institutions Other Than the IMF .............................15 


\section{INTRODUCTION}

The subject of this paper is how to reform IMF operations - in particular, IMF surveillance and its relationship with crisis lending - with the aim of providing stronger incentives for crisis prevention. Incentives could be improved in two ways: first, by providing more effective encouragement to policymakers - potential Fund borrowers and nonborrowers alike - to undertake actions that will prevent costly financial crises; second, by discouraging excessive capital flows to countries where average taxpayers bear the costs of crises but do not share the benefits of inflows owing to deficient financial regulation or fiscal policy.

For potential borrowers from the Fund, the main idea of the paper is that there ought to be a link between country behavior before a crisis and the country's access to IMF financing in a crisis. Linking country policies and IMF disbursements has, of course, been a fundamental principle of Fund operations since its inception: this linkage underlies the practice of "tranching" IMF loans and requiring specific policy actions prior to the release of the next tranche. The main difference with respect to current practice is that we propose to apply this principle to country behavior outside an IMF-supported program and prior to a request for assistance. In other words, we propose that access to IMF resources in crisis times be linked to the quality of economic policies in normal times. Even that idea is not new: the IMF's Contingent Credit Line (CCL), a facility created in 1998 and discontinued in 2003, would have allowed "prequalified" countries less onerous and cheaper access to large-scale crisis lending compared with their access through standard channels. But unlike the CCL and related proposals (Cordella and Levy Yeyati, 2005), this paper does not propose a new facility, but rather that "good" economic policies be a prerequisite for all countries that wish to access "large-scale" IMF support in the event of a crisis. In practice, this would require changes in the way in which the IMF conducts surveillance as well as in its access policies.

For Fund members with little or no prospect of borrowing from the IMF, linking surveillance to potential access to IMF credits would not make much sense. Still, for such countries, our proposal would be to use surveillance under Article IV to come to an explicit summary assessment, or rating, of the quality of a country's policies, and to lay out the main actions needed to address policy shortcomings. This rating would, in our view, help to strengthen domestic incentives for policy adjustments (including via the press and public opinion), would put pressure on the Fund to make sure its analysis and assessments were on the mark, and would help to clarify in the public mind the reasons for disagreements between the member and the Fund on the nature of needed policy changes. For potential borrowers from the Fund, the summary rating would have an added function as described previously, namely to set limits to the scale of potential access to Fund credits in periods of crisis.

The following section provides some background on the IMF crisis prevention and mitigation roles, briefly describes how that role was exercised in the past decade, and discusses reforms that the IMF has put in place in response to perceived shortcomings. Section III analyzes some limitations of IMF surveillance from the perspective of crisis prevention and discusses 
possible avenues to overcome these. The rationale for "ex ante conditionality" is presented in Section IV, and the practical aspects of our proposal, in Section V. Section VI concludes.

\section{BACKGROUND}

The IMF was created as a multilateral institution to promote economic integration among its members and allow a coordinated response to economic problems transmitted internationally through trade and payment flows. Its foundation in 1944 was motivated by the single most disastrous economic crisis in modern history, the Great Depression (James, 1996, Bordo and Eichengreen, 1998, Boughton, 2004). The Fund was given two tools to mitigate, and ideally prevent, future crises: surveillance over exchange rates and international payments policies of its members as a way of eliminating a key channel of international crisis transmission; and balance of payments lending, to offer members an alternative to external or fiscal adjustment mechanisms that would be harmful to the member or to other members. Equipped with these tools, the Fund helped facilitate the spectacular, relatively crisis-free growth and trade integration that followed World War II.

Sixty years after its foundation, the Fund's mandate remains as relevant as ever, but the economic environment in which it operates, and the adequacy of its tools in relation to its task, have greatly changed. The demise of the Bretton Woods system in the early 1970s eliminated surveillance over exchange rate parities as the main pillar of Fund activity. It was replaced by a broader and softer brand of surveillance, over a wide range of macroeconomic policy issues with relevance to exchange rates and payments, in which the Fund played the role of a confidential advisor rather than that of an arbiter. At the same time, the growth and stability of private capital markets between industrial countries shifted the Fund's role as a balance of payments lender from traditional clients such as France and Britain to developing countries; in particular, to emerging market countries with unstable access to international capital. Though no longer in need of Fund financial support, industrial countries remained critical for the Fund's crisis prevention mandate, however, both as creditor countries, and as a potential source of shocks and policy actions with global repercussions.

This is the environment in which the Fund has operated since the early 1980s, when it faced the first global financial crisis of the postwar period - the international debt crisis - and again in the latest wave of financial crises that began with the December 1994 collapse of the Mexican peso, climaxed in the aftermath of Russia's 1998 default, and ended with the crises in Argentina and Uruguay, 2001-2003. Looking to the future, today's advanced emerging market countries may well enjoy increasingly stable access to private capital markets thanks to steps they have taken to improve macroeconomic and structural policies, and their external financial structures and reserve positions. ${ }^{2}$ But it would be a mistake to extrapolate

\footnotetext{
${ }^{2}$ Another factor seen by some observers as suggesting more reliable access of middleincome countries to global capital markets in the future is the emergence of a deep emerging market asset class - with reliable demand from institutional and other investors. The current low level of emerging market spreads has given rise to such optimism. This said, it seems
} 
from today's benign global economic and financial conditions to the conclusion that emerging market countries will henceforth be immune from sudden stops (see Goldstein, 2005 , for a plausible scenario of another waive of crises over the next decade, and Rajan, $2005 \mathrm{~b}$, for a cautionary note on the implications of the current benign environment for future financial risks). Furthermore, the coming years are likely to witness the emergence of a number of large developing countries onto the scene of (possibly unstable access to) global capital markets. With the real possibility of a much larger emerging market segment of the Fund's membership, it would be premature to predict the demise of sudden stops or the global credit cycle. ${ }^{3}$ Beyond this, as middle income countries become increasingly important players, the potential for much larger spillovers from their quarter may well increase; preventing such crises tomorrow may well be an even greater challenge than it is today.

How has the Fund performed with regard to the prevention and mitigation of emerging market financial crises? Its record in the last decade suggests a mix of successes and failures. Good policy advice does not make headlines, but the Fund can surely take some credit for the enormous improvement in the standards of macroeconomic policy making around the world: from the defeat of inflation to the adoption of fiscal rules and inflation targeting frameworks, better debt management and the avoidance of dangerous debt structures. Economic management in emerging markets and many developing countries is vastly better today than it was 15 years ago, thanks in part to steady prodding and policy advice from the IMF. This said, these improvements did not come soon enough and were not sufficiently universal to prevent the boom-bust cycle of the 1990s. In some cases, the Fund also underestimated the risks of opening capital accounts in an environment of weak financial sector institutions. In consequence, there was a new wave of crises that led to requests for IMF assistance.

With regard to IMF-led rescues, a widely accepted view is that interventions in the aftermath of a currency crisis (for example, Mexico in February 1995, and the 1997 Asian crisis programs) shortened the duration of the crisis and put recoveries on a more solid footing. However, IMF crisis lending was not sufficient to prevent large contractions in output and current account reversals prior to those recoveries, the overshooting of the exchange rate, and international "contagion." As far as large scale lending with the purpose of fending off crisis is concerned, these have run the gamut from failure to full success. The rescue packages negotiated with Russia in July 1998 and Argentina in August 2001 did not prevent chaotic, painful crises a few months later. In contrast, the September 2002 Brazil package did help to avert what might have been a very destructive debt crisis with barely a dent in output. Other

premature to conclude only a few years after the last bust, that boom-bust cycles - a mainstay of international debt flows since the early $1820 \mathrm{~s}$ - are now a thing of the past. A more convincing diagnosis needs to await a turn in the global credit cycle-only then will we will know the extent to which present conditions reflect structural, rather than cyclical, factors.

${ }^{3}$ Borensztein (2004) argues that the share in world GDP of middle income countries with unstable capital market access could rise from 10 percent in 2000 to 35 percent in 2025 . 
cases fall in between: packages often did not succeed in averting a devaluation, but prevented a default and softened the blow of the crisis. Examples include the November 1998 Brazilian package and the December 2000 program augmentation with Turkey.

The Fund reacted to these experiences by rethinking many aspects of IMF surveillance and lending operations (Lane, 2005). A number of weaknesses were identified. First, surveillance had been insufficiently focused on vulnerabilities arising in the financial sector, and did not pay enough attention to the links between financial sector, corporate sector, and public sector balance sheets. Second, even when it succeeded in identifying critical vulnerabilities, surveillance had often been ineffective in persuading domestic policy makers to address them. Third, in some middle income countries - particularly those with continuous Fund presence and deemed regionally or systemically important - the prospect of IMF help may have encouraged excessive capital inflows and debt accumulation. Fourth, IMF packages may not have been sufficiently front loaded, and may also have been too small to prevent painful adjustments in countries experiencing a sudden loss of confidence. Fifth, IMF crisis lending had not done enough to prevent "innocent bystanders" from becoming the victims of regional or global contagion. Sixth, crisis lending had sometimes been used in attempts to avert crises that were mostly the result of unsustainable debt levels.

In response to these concerns, the IMF took steps to reform its operations at several levels:

- $\quad$ the Fund's analytical and diagnostic arsenal for identifying vulnerabilities and providing "early warning" was greatly expanded. This included a much greater focus on vulnerabilities related to the financial sector, debt structure and reserve management in the context of routine consultations; the development of specialized surveillance tools in the financial sector, particularly the financial sector assessment program (FSAP); the development of early warning systems; and closer surveillance of developments in international capital markets.

- $\quad$ transparency in IMF surveillance and lending operations has received much greater emphasis, in part to provide warning signals not just to policy makers, but also to capital markets and the public at large.

- two lending facilities were developed to respond specifically to capital account crises: the Supplemental Reserve Facility, which allowed access to large-scale lending on a short-term basis; and the Contingent Credit Line, which was supposed to allow prequalified countries large-scale access on a cheaper and less onerous basis than standard lending.

- $\quad$ an attempt was made to address concerns about IMF-induced moral hazard by introducing surcharges on high levels of credit outstanding, and setting a number of criteria for large scale lending (including that borrowers have sustainable debt levels, and good prospects of regaining access to private markets within the time that Fund resources would be outstanding, see IMF 2004a). 
- $\quad$ the Fund threw its weight behind the adoption of collective action clauses in sovereign bond markets as a means of facilitating crisis resolution;

- a "Sovereign Debt Restructuring Mechanism" (SDRM, see Krueger, 2002 and IMF, 2002) was proposed which would have created a framework for resolving debt crises in unsustainable debt cases, giving the Fund a second crisis resolution instrument in addition to large scale lending.

These innovations have strengthened the Fund's ability to carry out its mandate, improving its capacity to anticipate, warn against, and mitigate international financial crises. However, progress has not been equally strong in all areas. The most impressive improvements have been in the area of diagnostics and vulnerability analysis. The Fund is in a better position than ten years ago to assess country risks, and give warning both to policy makers and the public. In parallel with better advice, Fund transparency has strengthened the incentives to act on Fund warnings. Whether or not this creates sufficient incentives to change the minds of policy makers facing domestic incentives to delay reforms is an open question, however (see below). Finally, crisis lending is less ad hoc today than it was a decade ago, and provides stronger incentives for early repayment. But the most innovative ideas in the area of crisis resolution - the Contingent Credit Line, and the SDRM - were ultimately dropped, reflecting a lack of consensus within the membership on their design and desirability.

Notwithstanding significant improvements, the Fund continues to face the same fundamental question which it faced after the Mexican crisis, namely, how to reconcile effective crisis mitigation with the provision of good incentives to both policy makers and capital markets, thereby minimizing the risk that crises will occur in the first place. This is the question that we seek to address in the remainder of this paper.

\section{Avenues to Better Crisis Prevention}

The Fund's main instrument for crisis prevention is bilateral and multilateral surveillance. Whether or not surveillance is effective will depend on the degree to which it provides a compelling analysis of factors that can trigger a crisis, and on the willingness of policy makers to act on the Fund's analysis. To some extent, this is a matter of providing sound policy advice and communicating it persuasively. However, there may also be an issue with respect to conflicting interests. Policy makers may not take into account the effects of their actions on other countries and on the international system. In some cases, they may also not act in the best interests of their own citizens, owing to private interests or the influence of

\footnotetext{
${ }^{4}$ However, the debate on the SDRM did have the effect of focusing attention on collective action problems associated with the resolution of sovereign debt crises, leading to the inclusion of collective action clauses in bond contracts by an increasing number of sovereign issuers since 2004 (IMF, 2004b).
} 
particular groups. In such cases, it may well take stronger incentives to persuade policy makers to change course than sound advice and good communication.

The main mechanism on which the Fund has traditionally relied to encourage domestic policy changes is the exercise of peer pressure through the Executive Board. Peer pressure has important strengths: as a form of diplomacy, it can discretely mobilize the economic and political influence of the membership in ways that further the purposes of the institution. Moreover, peer pressure sits well with the role of the Fund as a confidential advisor: it is a way of applying suasion without destroying trust. But in cases when there are strong domestic or international interests at stake, peer pressure may simply not be enough - the Fund's lack of leverage, for good or ill, over the policies of countries that have no need to borrow from the Fund is by now well established. Beyond this, there is also the concern that peer pressure can sometimes turn into "peer protection," with countries given the benefit of the doubt that policy weaknesses will not prove serious enough to trigger a crisis. Peer protection could stem from the fact that similar vulnerabilities are prevalent across the membership, or that political or strategic interests interfere with the purposes of the Fund.

Recognizing these concerns, the Fund has sought to bring another factor into the picturegreater transparency - to improve the effectiveness of surveillance, and we see further scope to make use of this instrument in the future. The Fund has been pursuing greater transparency in its operations at least since the mid-1990s, including through presumed publication of staff reports and more extensive dissemination of information about members' adherence to various standards and codes. While evidence on the benefits of transparency at the international level is still tentative, ${ }^{5}$ we would nonetheless see merit in taking the process further-by bringing more clarity to the evaluation of country policies in Article IV reports. Concretely, this could be summarized in the form of a rating and a clear stipulation of the actions needed to remedy policy shortcomings in areas of the Fund's mandate. While some will object that this will turn the Fund into just another rating agency, our sense is that the breadth and objectivity of the Fund's expertise, informed as it is by an unparalleled range of cross-country experience, would result in value added of Fund ratings relative to those from the private sector. Others may caution that such a move would compromise the Fund's role as confidential advisor. However, what is suggested here is not that the Fund publicize confidential or market-sensitive data - in this regard, the current publication policies that allow such data to be deleted from staff reports could remain unchanged-but rather that the Fund give a clearer signal of its overall assessment of a country, which would help to remove ambiguities that are inherent under the status quo. ${ }^{6}$

5 There is evidence that IMF-sponsored transparency reforms have had an impact on the borrowing spreads of the countries that adopt them; see Glennerster and Shin (2003). Moreover, countries with low transparency are more likely to suffer banking crises as a result of financial liberalization (Mehrez and Kaufman, 2000; Barth, Caprio, and Levine, 2004).

${ }^{6}$ The World Bank has been moving in this direction with respect to IDA countries. In the late 1970s, it developed a set of numerical scores of country policies and institutions to guide

(continued) 
The regular publication of an easily understood assessment, or report card, would in our view make an important contribution to the public debate over key economic policy issues in member countries. It would increase pressure both on the Fund to make sure its analysis and recommendations were on the mark, and also on country authorities - e.g., through national parliaments and the press - to take Fund policy recommendations on board or alternatively articulate why they are wrong. Capital markets could also exert a disciplining effect, adding to the effectiveness of Fund surveillance.

Our proposal to publish country report cards for all members falls well short of defining a common standard of sound economic policy and giving the Fund the means to enforce adherence to that standard (including by imposing financial penalties, or threatening expulsion). That much stronger alternative, which draws on the role that Reports on Observance of Standards and Codes (ROSCs) already play in surveillance, presumes that it would be possible to obtain formal commitments by the Fund's membership to a set of standards in the areas of the Fund's mandate that would apply across the membership, and charging the Fund with vetting adherence to them - analogous to its past responsibility as overseer of the global system of fixed exchange rates.

The problem with this proposal is that there is little prospect that agreement on a common set of standards can be reached any time soon, not least because consensus is absent in the profession as to what might constitute such standards. Put differently, to operationalize such an approach, the standards of good behavior would have to be both comprehensive enough and nuanced enough to do justice to the different circumstances of each member countrywith objective criteria across a whole range of economic activity that leave little room for discretion or judgment. Given the complex relationship between country fundamentals and crises - and the diversity of opinion among economists and policy makers on this relationship - this would be a heroic task. Furthermore, enforcing such standards would not be easy, as the experience with the European Stability and Growth Pact, has shown.

But there is one aspect of the proposal that we think can be accommodated within the approach we advocate - which is to increase transparency about the link between objective indicators and the rating that the country receives in the course of surveillance. While judgment will always figure prominently in country assessments from surveillance, there is merit in being transparent about how the country's rating relates to objective indicators. Transparency in this direction would have the added advantage of reducing tensions between the Fund's surveillance and lending role, and helping to make surveillance a more independent activity, driven by the professional staff, on a more purely technical agenda.

IDA lending (Country Policy and Institutional Assessment, CPIA). In 2001, these ratings began to be published in quintile form, and the full index is to be published from early 2006. 
Beyond greater transparency, however, we would invoke another instrument to the cause of more effective crisis prevention, namely linking the quality of country policies as assessed under the Article IV to the level of access to Fund credits the member could have in the event of a crisis. Linking surveillance to access levels could strengthen incentives for good policies in two ways. First, through the prospect of higher potential access in the event that policy improvements identified by surveillance are carried out; and second, by providing a signal that could affect other capital flows, not unlike the signaling effects currently associated with IMF-supported programs. However, this signal would be provided without committing IMF resources. In this respect, linking potential access and a country's rating would operate in similar ways to the seals of approval embodied in the recently-approved Policy Support Instrument (PSI). Unlike either conventional programs or PSI signals, however, classifying countries in terms of potential access levels - like the country ratings behind them - would be universal across the membership. The signals under our approach would mostly rate economic management in normal times rather than endorse a particular adjustment program.

Aside from creating incentives for good policies, there is a second channel through which linking country policies to potential access levels could help to prevent crises. When policies or institutions are weak in the sense that they do not adequately reflect the interests of domestic citizens or impose significant external burdens, access to IMF resources can magnify the problem by allowing countries to receive extra debt flows, fueling financial or fiscal imbalances at the expense of the domestic taxpayer (Calomiris, 1998a, Jeanne and Zettelmeyer, 2001, 2005; and Rajan, 2004). By excluding countries from high access lending when governments fail to take reasonable crisis prevention steps, the IMF would remove this 'moral hazard' distortion, helping to reduce the likelihood that the prospect of the Fund's financial backing creates harm over and above that created by bad government itself. Hence, compared to the status quo, more selectivity in crisis lending could be beneficial even if it ultimately does not lead to better policies.

While the case for linking access to Fund resources to pre-crisis policies is conceptually simple, its practical implementation raises a host of questions. Which would be the critical elements that would enter into the country's rating and how would the thresholds for potential access levels be set? How should the Fund react when policies improve or deteriorate, or when there is a change in government? To the extent that deteriorations lead to the disqualification of a country from large scale lending, could this not trigger a crisis, defeating the main purpose of applying ex ante conditionality? What happens if the Fund is wrong, and disqualifying a country was really not justified? What if a crisis in a "disqualified" country has systemic implications, i.e. creates spillovers for other countries? Last but not least, does the proposed policy not raise a time consistency problem? How can the Fund say no to a country that is in crisis, based on policy actions taken perhaps several years before? These questions are the subject of the remaining sections of this paper.

\section{A Proposal}

In the preceding section, we made a case for linking the assessment of a country's policies in normal times - ordinarily, the subject of IMF surveillance — with the country's access to IMF 
lending in crisis times. How could this work in practice, and how would it deal with the problems and objections raised in the preceding paragraph?

As argued in the previous section, the core of a proposal in this area could be to use the annual Article IV consultation to generate a rating, or classification, of countries in terms of access levels. One possible implementation would have three access levels: level 1 - low access, below the Fund's current standard access limits, for countries with severe policy shortcomings and governance problems; level 3-exceptional access, for countries with very sound crisis prevention policies in areas described below; and level 2-access within, but not exceeding standard limits - for all other countries. IMF staff would propose such a classification as part of the "staff appraisal" in every consultation report. In addition, it would describe the specific policy adjustments that would be needed to reach a higher rating. The Executive Board would subsequently debate the staff's recommendation, and decide on a particular access classification. This process would apply to all members, and the ratingsand resulting access classifications - would be made public following the Board meeting.

The process of arriving at a rating would need to combine guidelines - including quantitative benchmarks - with judgment by the staff and Board, though judgments need to be transparent, and objective reasons provided, when judgment-based ratings differ from the mechanical rating from the guidelines. ${ }^{7}$ Guidelines would need to focus on financial sector regulation and supervision; debt levels and debt structure; reserve management; fiscal and exchange rate policy; and data dissemination. In contrast to some earlier proposals (Box 1), the purpose of these guidelines would not be to distinguish liquidity crises from crises caused by "solvency shocks:" so long as a country's debt remains (conditionally) sustainable, assisting a country in adjusting to solvency shocks in an orderly manner is one of the core functions of the IMF. Moreover, the guidelines would not have to be so stringent as to make traditional conditionality superfluous; the latter could continue to play its current role of encouraging orderly adjustment and safeguarding IMF resources. This said, if a country had strong fiscal policies, a well-regulated banking system and moderate levels of debt to begin with - to name some possible criteria for a " 3 " rating - then restoring solvency after a crisis would likely require less adjustment and reform than otherwise. In that sense, there would be a trade-off between classifications ex ante and conditionality ex post. It would be possible, moreover, to formalize this link, by making drawings by countries that qualify for the highest ex ante access category more automatic than for countries in lower categories.

\footnotetext{
${ }^{7}$ The guidelines could build on the emerging literature on threshold effects for the prevention of debt, currency, and banking crises (see, for example, Kaminski and Reinhart, 1999; Ghosh and Ghosh, 2003; and Manasse and Roubini, 2005).
} 


\section{Box 1. Designing Prequalification Criteria}

What criteria should determine whether countries "prequalify" for high access? Several recent studies and reports have discussed this issue.

- $\quad$ Calomiris (1998b) focused on four criteria related to the financial sector (free bank entry; market-based capital standards, reserve and securities requirements, and deposit insurance); limits on short-term government debt; and either floating exchange rates or-for countries with pegs-minimal international reserve levels and allowing banks to offer deposits in both domestic and foreign currency. The IMF would operate a discount window to lend to central banks of countries satisfying these requirements, against collateral of which 25 percent would be in foreign government securities.

- The International Financial Institutions Advisory Commission (2000) proposed prequalification criteria with the objective of restricting IMF support to liquidity crises only. It envisaged four conditions: (1) entry of foreign financial institutions to ensure a competitive and stable financial system; (2) adequate capitalization of commercial banks; (3) transparency in the public debt structure (including with regard to off-budget liabilities); and (4) a proper fiscal requirement to preclude irresponsible budget policies.

- $\quad$ The Council on Foreign Relations (CFR,1999) report was as interested in criteria that would induce a maximum country effort to prevent crises. Its conditions include: (1) avoiding large budget deficits; (2) prudent debt management, i.e., maintaining adequate liquidity and avoiding currency mismatches; (3) avoiding large current account deficits and highly overvalued exchange rates; (4) maintaining a strong and well-regulated banking system; and (5) public data disclosure standards.

- In the context of internal discussions on reforming the Contingent Credit Line (CCL, see IMF, 2003), CCL Eligibility Criteria for Constrained Discretion were designed to allow more automatic access to Fund resources, while maintaining safeguards. They included criteria on the fiscal deficit, public debt (including its structure), inflation, banking indicators (capital adequacy, liquidity, asset quality and stress tests), the current account, and reserves.

- $\quad$ Cohen and Portes (2004) focus on one criterion, namely, that countries abstain from public borrowing at spreads above a certain threshold. This would encourage early adjustment to prevent debt crises.

- $\quad$ Cordella and Levy Yeyati (2005) propose a small set of criteria that focus on debt sustainability and the currency and maturity composition of the public debt.

The CFR Task Force report is closest to the philosophy of this paper in the sense that it is guided by the idea of creating stronger incentives for crisis prevention, rather than by the idea of selecting a particular type of crisis (Calomiris, 1998b, IFIAC, 2000) or making IMF disbursement more automatic (IMF, 2003; Cordella and Levy Yeyati, 2005). It may go too far, however, to require all countries to exercise a maximum prevention effort, since in the presence of the IMF, somewhat less country effort at preventing crises than under autarky may be efficient (for example, by accumulating less reserves), and is indeed part of the intended purpose of the IMF. Moreover, the social costs of crisis prevention may differ from case to case.

The discussion so far addresses the question of how the Fund would classify countries in practice, and implicitly also how it would deal with an improvement in the quality of policies: in such cases, clearly, ratings would be upgraded to the extent that the country's policies justify such a move. But would our proposal have perverse effects in cases where a 
rating needed to be lowered - as was argued by critics of the IMF's Contingent Credit Lines (CCL) - in the sense that the Fund would end up triggering a crisis that our proposed system was designed to forestall? Downgrading a country may well have effects on capital flows to that country; indeed, this is one the intended purposes of the proposed ratings. However, it is unlikely to trigger a crisis. Unlike disqualification from the CCL, which required first and foremost that there would be "no expected need for IMF resources," a switch to a lower rating would not reflect the staff's expectation that a crisis is imminent. Rather, the Fund would be downgrading on the basis of policy changes that are likely to lead to a deterioration in the country's underlying vulnerabilities before actual distress arises. Hence a downgrade should leave the country enough time to implement corrective policies. ${ }^{8}$

Another important question is how sensitive the system would be to misclassification, and how potential errors could be corrected. Unlike the current approach to crisis lending, where there is really only one type of potential problem - countries may count on crisis lending in spite of poor pre-crisis policies - our proposal could suffer from two types of error: countries could be classified "high" when they should be classified "low", and vice-versa. What would the consequences be, in particular, of classifying a country type 2 that really deserves type 3 ? In this case, a country would enjoy a lower implicit guarantee, and hence would likely face higher costs of external financing and possibly smaller capital inflows than would be justified on the strength of its policies. Moreover, in the event the country were to face a crisis - an unlikely event since it is really a type 3 country, it would only be entitled to standard access.

To deal with this problem, our proposal might contain an "escape clause." For example, with a supermajority, and based on certain guidelines, the policy could allow the Board to overturn an earlier rating. Naturally, if used inappropriately, such an escape clause would have the potential of undermining the entire policy: if countries or financial markets expected that it would be generally invoked, there would be no difference between this policy and one without any ex ante classifications. Because there may be a strong temptation and political pressure to abuse the escape clause - conditioning on a crisis, large-scale lending will generally be optimal — our proposal requires a governance framework in which rules credibly constrain the use of discretion. Whether or not the Fund's current governance framework meets that standard, and areas for possible reform, are the subject of the next section.

\section{IMPLICATIONS FOR IMF GOVERNANCE}

The proposed approach to surveillance and crisis lending would place exceptional demands on the IMF's legitimacy and capacity to commit to a course of action. Classifying members via public ratings - and refusing lower-rated members high access in a crisis - creates such demands because it passes an unvarnished summary judgment over a member's policy, with

\footnotetext{
${ }^{8}$ We would also note that our proposal gets around other well-known problems with the CCL: a possible negative signal associated with applying for the facility; and lack of interest owing to the availability of large-scale IMF financing outside the CCL: see IMF, 2003.
} 
possibly harsh consequences. In addition, refusing a member exceptional access based on its pre-crisis policies raises a difficult time-consistency problem. Excluding governments with inadequate policies from the IMF's safety net may be in the ex ante interests of its citizens, but ex post - after a crisis has erupted - those citizens will want the IMF to mitigate the crisis. It may be very difficult for the IMF to say "no" in such circumstances.

Compared to many public organizations, the IMF arguably does fairly well as far as both legitimacy and commitment capacity are concerned. Legitimacy is achieved through the high technical standard of the Fund's work, the fact that all major decisions are taken by the Executive Board which represents the entire membership (including a representative of the country affected by a particular decision); and more recently, through transparency and dialogue with civil society. And the Fund's operations - most critically, conditionality which requires the suspension of disbursements if the conditions of a loan have been violateddemonstrate that the IMF has some capacity to commit. While this capacity is not perfectas witnessed by the fact that waivers, which allow disbursement when conditions were missed for justifiable reasons, are sometimes controversial - conditionality is nevertheless taken seriously by most countries that borrow from the Fund, as well as by public opinion.

In view of the challenges posed by the proposal developed above, however, the fact that the IMF does reasonably well in terms of legitimacy and commitment capacity may not suffice. Against this background, we now turn to some proposals for IMF governance reform.

\section{A. Improving the IMF's Ability to Commit}

Because IMF decisions include difficult judgments that impact the welfare of sovereign nations, and because political backing is essential to enforce the repayment of its loans, the IMF clearly requires close oversight by its members. It could not function as a completely technocratic body. However, there are several ways in which such oversight could be exercised. One is direct political supervision, as in a government ministry in which civil servants are subordinate to political representatives who approve all key decisions. An alternative is political accountability, as with parliamentarians whose decisions are guided by laws and their conscience, but who are periodically accountable to their electorates.

Though the governance structure of the Fund contains both aspects (van Houtven, 2002), direct political supervision dominates in practice. While the Managing Director is accountable to the Executive Board and Executive Directors in turn to their constituencies, the Board has responsibility for all key operational decisions, and many national authorities exercise direct supervision over their Executive Directors. The emphasis on direct political supervision is shared with many other international organizations, though exceptions exist (for example, the ECB, the dispute settlement process of the WTO, and organizations with comparatively narrow technical tasks; see Box 2 ).

In part, the reliance on direct supervision rather than accountability can be justified by the lack of a clear yardstick to evaluate IMF operations. Fund decisions - unlike those of most modern central banks - have multiple dimensions, and success or failure cannot be judged as 
one judges a central bank's ability to hit its preannounced inflation target. From the point of view of time consistency and capacity to commit, however, the direct supervision model has some disadvantages. Commitment can be created at two levels: at the constitutional stage, by defining a set of rules that the institution must adhere to and that is difficult to overturn and, through practice, by creating a reputation that benefits day to day operations and that would be costly to lose. At the constitutional level, governments have a joint interest in creating an international institution that sticks to a particular mandate, filling gaps left by national policies. But at the policy decision stage, they may be, quite naturally, more interested in

\section{Box 2. Governance of Some International Institutions Other Than the IMF}

The governance of several important international institutions is characterized by close supervision from member country authorities. A good example is the Security Council, the United Nation's (U.N.'s) main decision-making body, which functions in continuous session and whose 15 members are represented at all times at the seat of the U.N. A similar model applies to decision making at the main international financial institutions. The Executive Directors supervise the day-to-day operations of the institution, and meet as often as business requires, not only at the Fund and at the World Bank, but also at the regional development banks.

Supervision by member countries is not as close and continuous in many other international institutions, such as the World Trade Organization (WTO) or a number of U.N. specialized agencies, reflecting the nature of their activities. The main task of these institutions is to set standards, provide technical assistance, and act as neutral fora where member countries can negotiate agreements and debate policy. For example, member countries do not have permanent representation in the executive of the WTO secretariat, which has no decision-making power.

Some international institutions have a governance structure that is designed explicitly to guarantee independence from the political authorities in member countries. This is naturally the case for judicial institutions, such as the International Court of Justice, but also for some non-judicial ones such as the European Central Bank (ECB). Although the members of the Executive Board of the ECB are appointed by the Heads of State or Government of the euro area countries, neither the ECB nor the national central banks, nor any member of their decision-making bodies, is allowed to seek or take instructions from European Union (EU) institutions or bodies, from any government of an EU Member State, or from any other body. The same applies to the quasi-judicial panels that settle disputes between WTO members.

The allocation of voting power generally depends on whether the international institution's purpose is financial or not. For financial institutions, voting power is related to, though not necessarily proportional to, the country's share in the capital of the institution. For other international institutions, the principle of one-country-one-vote typically applies, although additional provisions (such as the status of permanent member of the U.N. Security Council) may considerably enhance the power of some countries. In some cases, such as the WTO, voting is dispensed with altogether, and decisions are taken by consensus.

whether a decision furthers their national interests. This may dilute the usual reputational mechanism for establishing commitment. In addition, the perception that Fund advice or conditionality is influenced by shareholder politics can also undermine the institution's legitimacy, and hence countries' willingness to accept Fund policy recommendations.

To the extent that more effective crisis prevention places even higher demands on commitment and legitimacy than is presently the case, this suggests rebalancing the way that 
political oversight is currently exercised, with less direct supervision and more accountability. ${ }^{9}$ One could imagine a variety of steps in that direction, primarily at the level of the Executive Board as the key organ charged with operational decisions. For example, appointed chairs could be abolished and the length of Directors' terms could be raised to buttress their day-to-day independence from national capitals. The Board's size could be reduced to ensure that all members are represented in multi-country constituencies where the influence of individual capitals would diminish. A more far-reaching alternative would be to dissolve the tie between constituencies and specific Directors altogether, with the entire Board being selected through some process designed to produce a group of individuals with strong technical skills, broad geographic representation, and a deep commitment to the mandate of the Fund as stipulated in the Articles, and each such Director casting one vote.

Could this alternative still provide adequate political oversight demanded by the Fund's shareholders? Much would depend on the extent to which accountability was strengthened, a challenge given the lack of an obvious yardstick against which to measure IMF performance. But, as several reports of the IMF's Independent Evaluation Office demonstrate, it is possible for an independent monitor to arrive at a judgment about the quality of IMF decisions in surveillance or lending contexts. To the extent that the IMF's rules allow for exceptions, performance could be assessed on the strength of the arguments used to justify exceptions, as in the case of a central bank required to justify why an inflation target is not met. Based on this independent assessment, the Board as a whole could be subjected to a vote of confidence by the membership (represented by the Board of Governors) at regular intervals, say the time of the Annual Meetings, introducing a higher-frequency form of accountability that could help to counterbalance the loss of political oversight through direct supervision.

\section{B. Enhancing IMF Legitimacy}

More accountability — and less day-to-day oversight by a small group of creditor countriesis likely to increase the IMF's perceived legitimacy in the developing countries most affected by its decisions. But even with more accountability, there could still be a democratic deficit in the Fund - given the large aggregate population but limited voting power of developing countries in the IMF. While existing quota formulas do not in fact justify a higher quota share for developing countries (except over time, to the extent that they grow faster than industrial countries, as is the case for emerging Asia), it is easy to imagine other formulas that could have such an impact. Some have argued that valuing GDP at purchasing power parity (PPP), rather than market exchange rates, would provide a better picture of developing countries' global economic weight (Buira, 2003). Alternatively, GDP at market exchange rates could be retained as the best measure of global economic power, but the formula could be extended to include population, in recognition of the ethical (and democratic) principle that all else equal, countries with larger populations should have more influence.

\footnotetext{
${ }^{9}$ For some related proposals, see De Gregorio and others (2000), Cottarelli (2005), and Rajan (2005a).
} 
Using either approach, it would be possible to justify an increase in developing-country quota shares. Notably, however, these changes need not result in a loss of creditor-country control over a majority of votes, or even in an end to the veto power of the Fund's largest shareholder (see Kelkar, et al., 2004, for a discussion). Other possibilities have been proposed, including a consolidation of European chairs at the Board, which could give the European Union an equal share to that of the United States, and free up considerable room to expand the shares of developing countries, especially in emerging Asia (van Houtven, 2004).

A remaining problem is that even taking into account PPP-adjusted GDPs, or possibly population size, in the quota formulas, a legitimacy problem might still be present in the case of countries that are both poor and not populous - such as sub-Saharan African countriesbut that are much affected by the Fund's decisions. To address this concern, "basic votes," which are allocated equally across countries, could be revived as a vehicle for raising the voting share of small members. When the IMF was established, basic votes amounted to 11.3 percent of total IMF votes; but they have since fallen to only about 2.1 percent, as quotas were increased but the number of basic votes remained fixed. Although it would require amending the IMF's articles, restoring basic votes to their original share of total votes may be desirable as a means of giving small, poor countries greater voice in the institution, and in this way helping to improve the Fund's legitimacy with the membership as a whole.

In tandem with more democracy at the level of quotas and voting shares, steps should also be taken to make the selection process of the Managing Director both more democratic and meritocratic. Currently, this procedure is controlled by the creditor countries, and particularly the European countries. Though Managing Directors have typically earned the respect and trust of the membership at large, the perception that the Managing Director is selected by a particular group of countries that also decide on future extensions of his or her appointment could reduce the Fund's legitimacy and credibility as a neutral institution that is committed only to its purposes. Instead, the selection process should be geared towards a candidate that is best positioned to exercise strong leadership in delivering the Fund's message, even if this message conflicts with the policies of large members. This could be achieved through a twostep process, in which the Governors of the Fund select a group of experts with wide international representation, and this group in turn makes a selection on meritocratic grounds.

\section{CONCLUSION}

This paper has developed a proposal to increase the effectiveness of Fund surveillance in preventing crises, with implications for the institution's crisis lending policies and its internal governance. The proposal involves recasting surveillance in two ways and depends upon governance reforms that would allow the Fund to more reliably commit to rules it sets for itself while increasing the perceived legitimacy of its decisions across the membership.

- $\quad$ First, Article IV surveillance would henceforth result in a summary assessment or rating of the quality of a country's policies, and this rating would be published following the Board meeting that set the rating. Surveillance would also clearly set 
out the main policy actions a member would need to take to address shortcomings identified in the Article IV report and improve its rating. This process would apply to the entire membership — rather than just to potential borrowers from the Fund - on the grounds that large creditor countries, given their systemic importance, also have an important role to play in mitigating crisis risks for all members. The proposal to have Article IV surveillance culminate in a summary public rating would increase pressure on the Fund to make sure its analysis and recommendations were on the mark, and also on country authorities - for example, through national parliaments and the press - to take Fund crisis-prevention policy recommendations on board or alternatively articulate why they are wrong; capital markets could also exert a disciplining effect, adding to the effectiveness of Fund surveillance.

- Second, there would be a tight link between the rating a country received in the course of surveillance and the potential access level to Fund resources it would have in the event of a crisis. Put differently, the extent of IMF insurance that the country could avail itself of in a crisis would depend on the assessment of its policies in noncrisis periods (rather than, as at present, on the forward-looking policy commitments of the member under a program). It is worth mentioning that, in contrast to the CCL and related proposals, because the availability of Fund insurance would be spelled out ex ante for all members, there would be no need to "apply" for this insurance; another main drawback of the CCL would also be avoided under our proposal-namely the potential for large-scale Fund financing for even nonsubscribers to the facility. The paper spells out the main elements of how to operationalize our proposal and tries to rebut some possible criticisms it could face.

- $\quad$ Third, because this proposal would place added demands on IMF governance - given the need to commit to a predefined course of action through ex ante public ratings and the (possibly harsh) consequences that flow from this for lending policy - the paper goes on to make some proposals geared toward improving the Fund's ability to stick to rules it sets for itself and increasing the perceived legitimacy of its decisions across the entire membership. In particular, we suggest rebalancing the way political oversight is exercised, moving away from day-to-day direct supervision by national capitals and toward longer-term accountability of the Board over the extent to which the totality of its decisions in a period (say a year) furthers the global mandate of the institution; we also make a number of suggestions that could help to improve perceived legitimacy of Fund decisions in some segments of the membership, particularly where voice and representation seem to be out of kilter with economic realities or even democratic principles.

We see our proposal as following in a continuum of efforts by the institution and the membership to improve the Fund's ability to carry out its crisis prevention mandate. While there are always trade-offs in any proposed institutional reform, we believe that the proposals in this paper could be helpful in furthering the Fund's ability to more effectively fulfill its crisis-prevention mandate in the coming years. 


\section{References}

Barth, James R., Gerard Caprio, and Ross Levine, 2004, "Bank Regulation and Supervision: What Works Best?," Journal of Financial Intermediation, Vol. 13 (April), pp. 205-248.

Bordo, Michael D., and Barry Eichengreen, 1998, "Implications of the Great Depression for the Development of the International Monetary System," in Michael Bordo, Claudia Goldin, and Eugene White, The Defining Moment: The Great Depression and the American Economy in the Twentieth Century (Chicago: University of Chicago Press), pp. 403-53.

Borensztein, Eduardo, 2004, "Forces Shaping the IMF of Tomorrow," Finance and Development, Vol. 41 (September), pp. 16-17.

Boughton, James, 2004, "The IMF and the Force of History: Ten Events and Ten Ideas that Have Shaped the Institution," IMF Working Paper 04/75 (Washington: International Monetary Fund).

Buira, Ariel, 2003, "The Governance of the IMF in a Global Economy," in, Challenges to the World Bank and IMF, ed. by Ariel Buira (London: Anthem Press).

Calomiris, Charles W. 1998a, “The IMF's Imprudent Role as Lender of Last Resort," Cato Journal, Vol. 17, No. 3, pp. 275-94.

, 1998b, "Blueprints for a New Global Financial Architecture" (unpublished; Washington: available on the website of the American Enterprise Institute, http://www.aei.org).

Cohen, Daniel, and Richard Portes, 2004, "Towards a Lender of First Resort," CEPR Discussion Paper No. 4615 (London: Center for Economic Policy Research).

Cordella, Tito, and Eduardo Levy Yeyati, “A (New) Country Insurance Facility,” IMF Working Paper 05/23 (Washington: International Monetary Fund).

Cottarelli, Carlo, 2005 "Efficiency and Legitimacy: Trade-Offs in IMF Governance," IMF Working Paper 05/107 (Washington: International Monetary Fund).

Council on Foreign Relations Task Force, 1999, Safeguarding Prosperity in a Global Financial System. The Future International Financial Architecture (Washington: Institute for International Economics). 
De Gregorio, José, Barry Eichengreen, Takatoshi Ito, and Charles Wyplosz, 2000, An Independent and Accountable IMF, Geneva Reports on the World Economy Report 1, (London: Center for Economic Policy Research), September.

Ghosh, Swati R., and Atish R. Ghosh, 2003, "Structural Vulnerabilities and Currency Crises," IMF Staff Papers, Vol. 50, No. 3, pp. 481-507.

Glennerster, Rachel, and Yongseok Shin, 2003, "Is Transparency Good for You, and Can the IMF Help?” IMF Working Paper 03/132 (Washington: International Monetary Fund).

International Financial Institutions Advisory Commission, 2000, Report (Washington: United States Congress, available on the website of the Joint Economic Committee, http://www.house.gov/jec/imf/meltzer.htm).

International Monetary Fund, 2002, "The Design of the Sovereign Debt Restructuring Mechanism - Further Considerations," (available on the IMF's website, http://www.imf.org; Washington: International Monetary Fund).

_ 2003, Policy Development and Review Department, "Review of Contingent Credit Lines," February 11(available on the IMF's website; Washington: International Monetary Fund).

__ 2004a, Policy Development and Review and Finance Departments, "Review of Exceptional Access Policy," March 23 (available on the IMF's website; Washington: International Monetary Fund).

— 2004b, "Progress Report to the International Monetary and Financial Committee on Crisis Resolution," September 28 (available on the IMF's website; Washington: International Monetary Fund).

James, Harold, 1996, International Monetary Cooperation Since Bretton Woods (Washington and Oxford: International Monetary Fund and Oxford University Press).

Jeanne, Olivier, 2000, and Jeromin Zettelmeyer, 2001, "International Bailouts, Moral Hazard and Conditionality," Economic Policy, Vol. 33, pp. 409-32.

— , and Jeromin Zettelmeyer, 2005, "The Mussa Theorem (and Other Results on IMF-Induced Moral Hazard)," IMF Staff Papers, Vol. 52, Special Issue, pp. 64-84.

Kaminski, Graciela, and Carmen Reinhart, 1999, "The Twin Crises: The Causes of Banking and Balance of Payments Problems," American Economic Review, Vol. 89 (June), pp. 473-500.

Kelkar, Vijay, Vikash Yadav, and Praveen Chaudhry, 2004, "Reforming the Governance of the International Monetary Fund," World Economy, Vol. 27, Issue 5 (May), pp. 727-43. 
Krueger, Anne O., 2002, A New Approach to Sovereign Debt Restructuring (Washington: International Monetary Fund)

Lane, Timothy, 2005, "Tensions in the Role of the IMF and Directions for Reform," World Economics, Vol. 6, No. 2 (April-June).

Manasse, Paolo, and Nouriel Roubini, 2005, “ 'Rules of Thumb' for Sovereign Debt Crises,” IMF Working Paper 05/42 (Washington: International Monetary Fund).

Mehrez, Gil, and Daniel Kaufmann, 2000, "Transparency, Liberalization, and Banking Crisis," Policy Research Working Paper No. WPS 2286 (Washington: World Bank Group).

Rajan, Raghuram G., 2005a, "Institutional Reform and Sovereign Debt Crises," Cato Journal, Vol. 25 (Winter 2005), pp. 17-24.

— , 2005b, "The Greenspan Era: Lessons for the Future," paper presented at the Jackson Hole Symposium on Financial Markets, Financial Fragility, and Central Banking, August 27, 2005 (available on the IMF's website at http://www.imf.org).

Van Houtven, Leo, 2002, Governance of the IMF: Decision Making, Institutional Oversight, Transparency and Accountability, IMF Pamphlet Series, No. 53 (Washington: International Monetary Fund). 